\title{
HPV infection and oral carcinogenesis
}

\author{
Correspondence: \\ Medicina Bucal. Unidad de Patología Oral y Maxilofacial. \\ Facultad de Medicina y Odontología. \\ Universidad del País Vasco EHU \\ Barrio Sarriena $s / n$ \\ Leioa 48940 Vizcaya Spain \\ ameliaacha@gmail.com
}

\begin{abstract}
Acha-Sagredo A, Ruesga MT, Aguirregaviria JI, Aguirre JM. HPV infection and oral carcinogenesis. Med Oral Patol Oral Cir Bucal. 2010 Jan $1 ; 15(1): \mathrm{e} 1-2$.

http://www.medicinaoral.com/medoralfree01/v15i1/medoralv15ilp1.pdf
\end{abstract}

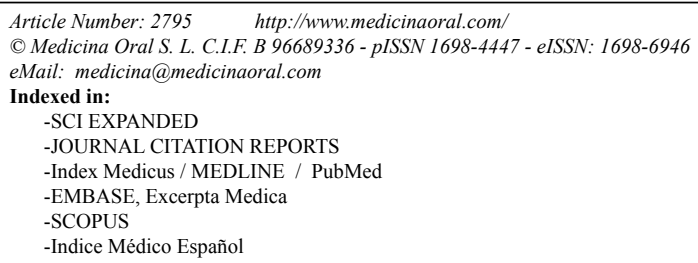

To the Editor,

High risk human papilloma viruses (HPV) have been found in head and neck squamous cell carcinomas (HNSCC), particularly in oropharyngeal carcinomas (1). Nevertheless, there are some controversial aspects regarding this issue (2) such as whether the HPV infection is a temporary or a persistent oral infection in these patients.

Recently, Chuang et al. (3) have associated the presence of HPV-16 DNA in surveillance salivary rinses with a significant risk for recurrence in HNSCC.

We hypothesized that the improved prognosis of many patients with HPV-related oropharyngeal carcinoma is due to the temporary nature of the infection, and therefore in the absence of lesions no HPV genomic DNA is detected in oral smears.

We have analyzed a longitudinal cohort of 47 patients who had been treated for a previous oral squamous cell carcinoma (OSCC) without any precancerous or cancerous oral lesion when the oral smear was collected. The group was composed of 29 men and 18 women with a mean age of 62.02 years (45-87 years). Primary OSCC sites were tongue $(44.6 \%)$, floor of the mouth $(31.9 \%)$, oropharynx (17\%), gingiva (12.7\%) and buccal muco- sa $(8.5 \%)$. Tumours were classified as T1 $(53.3 \%)$, T2 (37.7\%), T3 (2.2\%) and T4 (6.6\%).

A cytological brush (CytobrushTM) was vigorously swabbed over the oral cavity. Cytological samples were centrifuged at $1500 \mathrm{rpm}$ for 15 minutes and washed with phosphate-buffered saline (PBS) to obtain the cellular pellet. DNA was extracted following the classical proteinase-K, phenol/chloroform method and precipitated with ethanol. The detection of HPV genomic DNA was performed using the Papitype kit (ProgenieMolecular S.L, Valencia. Spain). In brief, a polymerasechain reaction (PCR) targeting the $\mathrm{L} 1$ region of the viral genome, harbouring an internal control to avoid false negatives, was carried out. Subsequently, and in HPV+ samples, typing was performed using a restriction fragment length polymorphism (RFLP).

To our surprise, no HPV genomic DNA was detected in any of the samples. These results agree with other published data $(4,5)$ which indicate that the HPV infection, when present in oral cancer patients, is temporary and probably related with the presence of a malignant or premalignant lesion.

Conscious of the limitations of our study, we think, as other authors (3), that the presence of HPV genomic DNA in oral smears may be used as a biomarker in 
OSCC patients. Additionally, we would like to address that the use of oral smears to detect HPV genomic DNA is an easy and harmless methodology $(6,7)$.

\section{References}

1. D’Souza G, Kreimer AR, Viscidi R, Pawlita M, Fakhry C, Koch WM, et al. Case-control study of human papillomavirus and oropharyngeal cancer. N Engl J Med. 2007;356:1944-56.

2. Pintos J, Black MJ, Sadeghi N, Ghadirian P, Zeitouni AG, Viscidi $\mathrm{RP}$, et al. Human papillomavirus infection and oral cancer: a casecontrol study in Montreal, Canada. Oral Oncol. 2008;44:242-50.

3. Chuang AY, Chuang TC, Chang S, Zhou S, Begum S, Westra WH, et al. Presence of HPV DNA in convalescent salivary rinses is an adverse prognostic marker in head and neck squamous cell carcinoma. Oral Oncol. 2008;44:915-9.

4. Schwartz SM, Daling JR, Doody DR, Wipf GC, Carter JJ, Madeleine MM, et al. Oral cancer risk in relation to sexual history and evidence of human papillomavirus infection. J Natl Cancer Inst. 1998;90:1626-36.

5. Herrero R, Castellsagué X, Pawlita M, Lissowska J, Kee F, Balaram P, et al. Human papillomavirus and oral cancer: the International Agency for Research on Cancer multicenter study. J Natl Cancer Inst. 2003;95:1772-83.

6. Acha A, Ruesga MT, Rodríguez MJ, Martínez de Pancorbo MA, Aguirre JM. Applications of the oral scraped (exfoliative) cytology in oral cancer and precancer. Med Oral Patol Oral Cir Bucal. 2005;10:95-102.

7. Trullenque-Eriksson A, Muñoz-Corcuera M, Campo-Trapero J, Cano-Sánchez J, Bascones-Martínez A. Analysis of new diagnostic methods in suspicious lesions of the oral mucosa. Med Oral Patol Oral Cir Bucal. 2009;14:E210-6.

\section{Acknowledgements}

Research granted by: Carlos III Health Institute - FIS (PI021271) and Department of Education, Universities and Research, Government of the Basque Country (IT-192-07). 